\title{
Genotoxicity of Superparamagnetic Iron Oxide Nanoparticles in Granulosa Cells
}

\author{
Marina Pöttler ${ }^{1, *}$, Andreas Staicu ${ }^{1}$, Jan Zaloga ${ }^{1}$, Harald Unterweger ${ }^{1}$, Bianca Weigel ${ }^{1}$, \\ Eveline Schreiber ${ }^{1}$, Simone Hofmann ${ }^{2}$, Irmi Wiest ${ }^{2}$, Udo Jeschke ${ }^{2}$, Christoph Alexiou ${ }^{1}$ \\ and Christina Janko ${ }^{1}$
}

Received: 31 August 2015 ; Accepted: 15 October 2015 ; Published: 3 November 2015

Academic Editor: Yuping Bao

1 Department of Otorhinolaryngology, Head and Neck Surgery, Section for Experimental Oncology and Nanomedicine (SEON), Else Kröner-Fresenius-Stiftung Professorship, University Hospital Erlangen, Glückstraße 10a, Erlangen 91054, Germany; andreas.staicu@uk-erlangen.de (A.S.);

jan.zaloga@uk-erlangen.de (J.Z.); harald.unterweger@uk-erlangen.de (H.U.);

bianca.weigel@uk-erlangen.de (B.W.); eveline.schreiber@uk-erlangen.de (E.S.);

christoph.alexiou@uk-erlangen.de (C.A.); christina.janko@uk-erlangen.de (C.J.)

2 Department of Obstetrics and Gynecology, Ludwig Maximilians University of Munich, Maistraße 11, Munich 80337, Germany; simone.hofmann@med.uni-muenchen.de (S.H.);

irmgard.wiest@med.uni-muenchen.de (I.W.); udo.jeschke@med.uni-muenchen.de (U.J.)

* Correspondence: marina.poettler@uk-erlangen.de; Tel.: +49-9131-8543-985; Fax: +49-9131-8534-828

\begin{abstract}
Nanoparticles that are aimed at targeting cancer cells, but sparing healthy tissue provide an attractive platform of implementation for hyperthermia or as carriers of chemotherapeutics. According to the literature, diverse effects of nanoparticles relating to mammalian reproductive tissue are described. To address the impact of nanoparticles on cyto- and genotoxicity concerning the reproductive system, we examined the effect of superparamagnetic iron oxide nanoparticles (SPIONs) on granulosa cells, which are very important for ovarian function and female fertility. Human granulosa cells (HLG-5) were treated with SPIONs, either coated with lauric acid (SEONLA) only, or additionally with a protein corona of bovine serum albumin (BSA; SEON ${ }^{\mathrm{LA}-B S A}$ ), or with dextran (SEON ${ }^{\mathrm{DEX}}$ ). Both micronuclei testing and the detection of $\gamma \mathrm{H} 2 \mathrm{~A}$.X revealed no genotoxic effects of SEON ${ }^{\mathrm{LA}-\mathrm{BSA}}, \mathrm{SEON}{ }^{\mathrm{DEX}}$ or SEON ${ }^{\mathrm{LA}}$. Thus, it was demonstrated that different coatings of SPIONs improve biocompatibility, especially in terms of genotoxicity towards cells of the reproductive system.
\end{abstract}

Keywords: superparamagnetic iron oxide nanoparticles; protein corona; cancer therapy and diagnosis; reproductive health; granulosa cells

\section{Introduction}

Superparamagnetic iron oxide nanoparticles (SPIONs) have been widely investigated for many years now. Due to their exceptional magnetic, electronic and optical properties, they have turned out to be promising candidates for research and future use in an industrial or clinical setting. Especially for medical and scientific applications ranging from in vitro diagnostic tests, in vivo imaging, targeted drug delivery and tissue regeneration, SPIONs are capable candidates.

In particular, SPION-based contrast enhancement in magnetic resonance imaging (MRI) [1], magnetic hyperthermia treatment [2] and magnetic drug targeting (MDT) [3,4] are of special interest in the therapy and diagnosis of cancer and other diseases [3,5]. Their incorporation into therapeutic drugs and their parallel use in imaging processes enables SPIONs to become "theranostic" agents. Additionally, the use of SPIONs in magnetic tissue engineering is a new concept in biomedicine [6]. 
SPIONs usually consist of iron oxide cores measuring 5-20 $\mathrm{nm}$ in diameter made of magnetite $\left(\mathrm{Fe}_{3} \mathrm{O}_{4}\right)$ and its oxidized form maghemite $\left(\gamma-\mathrm{Fe}_{2} \mathrm{O}_{3}\right)$. To increase their colloidal stability and biocompatibility, these iron oxide cores are coated with, e.g., long-chain fatty acids [7] or biocompatible polymers as chitosan or dextran [8]. Commercially accessible contrast agents like Sinerem, Resovist, Supravist and Ferridex have a surface coating of dextran or carboxydextran [9]. The formation of a surrounding protein corona also contributes to the stabilization and biocompatibility of iron oxide nanoparticles [10].

Because of the highly catalytic properties of nanoparticle surfaces [11,12], their coating may work as a barrier and could reduce their toxic potential. Especially for iron oxide nanoparticles, Fenton-like reactions caused by released iron ions [13] or on the nanoparticle surface have been under discussion as triggering toxic effects [14]. Here, hydroxyl radicals are generated which are highly reactive and react with almost all cellular macromolecules such as lipids, proteins, and carbohydrates. Since nanotoxicity has been identified as being a tiered process starting with oxidative stress, the oxidation of cellular components may finally result in cell death [12]. It is an important fact that oxidative stress has also been identified as causing DNA damage such as abasic DNA sites, oxidized bases along with single and double strand DNA breaks [15].

For the future translation of SPIONs from bench to bedside, it is crucial to evaluate their biocompatibility and exclude potential toxic effects. Only few studies have focused to date on the effect of nanoparticles on reproductive cells. Since iron oxide nanoparticles have previously been shown to cross the placenta and accumulate in the fetus [16], applied medical nanoparticles must be absolutely biocompatible and safe. Here, granulosa cells are used as a model system for female reproductive tissue. These cells play a key role in sustaining ovarian function, health and female fertility and, are thus closely associated with the development of the female gamete. In this study, we compare the effect of SPIONs which were coated with different surface moieties. The first two systems, SEON ${ }^{\mathrm{LA}}$ and SEON ${ }^{\mathrm{LA}-\mathrm{BSA}}$ derive from the same coprecipitation synthesis where the particles are stabilized in situ by a double layer of lauric acid [17]. The difference is that SEON ${ }^{\mathrm{LA}-B S A}$ is additionally coated with a BSA shell, which greatly improves colloidal stability, influences biocompatibility and enhances its capacity for drug loading. In a recent, detailed study, we comprehensively characterized the properties of these two systems [10]. The third system is synthesized also by coprecipitation, but a different surface coating strategy was chosen: SEON ${ }^{\mathrm{DEX}}$ particles are directly precipitated in dextran containing iron solution. This enables narrow core size distribution and high colloidal stability by steric stabilization. These particles have also been comprehensively characterized earlier [18]. As an important aspect, we demonstrated that the appropriate coating of iron oxide nanoparticles ensures their biocompatibility.

\section{Results and Discussion}

\subsection{Uptake of Iron Oxide Nanoparticles by Granulosa Cells}

Nanoparticle-induced toxicity is highly correlated with cellular uptake. Therefore, we measured the cellular iron content on equal terms as in toxicity tests. Granulosa cells were incubated for $48 \mathrm{~h}$ with three different superparamagnetic iron oxide nanoparticles: SEON ${ }^{\mathrm{LA}}$ (coated with lauric acid only), SEON ${ }^{\mathrm{LA}-\mathrm{BSA}}$ (coated with lauric acid and albumin) and SEON ${ }^{\mathrm{DEX}}$ (coated with dextran). After incubation, the cells were washed and the amount of iron was subsequently analyzed from cell lysates by microwave plasma atomic emission spectroscopy (MP-AES). Evaluation of cellular iron content indicated that SEON ${ }^{\mathrm{LA}}$ were effectively taken up by cells, whereas SEON ${ }^{\mathrm{LA}-\mathrm{BSA}}$ were only weakly taken up and SEON ${ }^{\mathrm{DEX}}$ not at all (Figure 1). These results are in concordance with previous investigations on uptake of SEON nanoparticles by primary human umbilical vein endothelial cells (HUVEC) and by T-cells (Jurkat) [19,20]. Other groups also showed that cellular uptake efficiency of iron oxide nanoparticles is dependent on surface coating and the protein corona [21,22]. To sum up, 
the presence of a pre-formed albumin protein corona (SEON ${ }^{\mathrm{LA}-\mathrm{BSA}}$ ) reduces cellular uptake of the SEON particles remarkably compared to particles stabilized only by a lauric acid layer (SEON ${ }^{\mathrm{LA}}$ ).
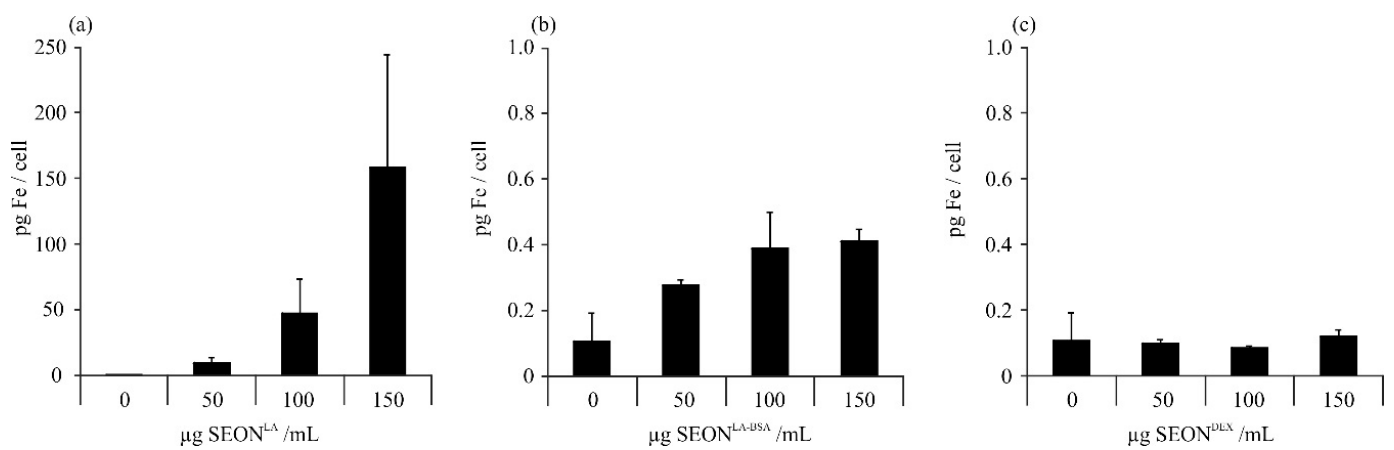

Figure 1. Uptake of SPIONs by HLG-5 cells. Cells were incubated with 50, 100 or $150 \mu \mathrm{g} / \mathrm{mL}$ of (a) $\mathrm{SEON}^{\mathrm{LA}}$; (b) SEON ${ }^{\mathrm{LA}-\mathrm{BSA}}$; or (c) SEON ${ }^{\mathrm{DEX}}$ for $48 \mathrm{~h}$. The cellular iron content was analyzed from cell lysates by microwave plasma atomic emission spectroscopy (MP-AES). The mean values of $n=3$ with standard deviations are shown.

\subsection{Viability of Granulosa Cells after Incubation with SPION}

Viability of HLG-5 granulosa cells was determined using flow cytometry. The cells were stained for phosphatidylserine exposure using Annexin V-Fitc $(\mathrm{AxV})$ and plasma membrane integrity using propidium iodide (PI). AxV/PI data were confirmed by staining for mitochondrial membrane potential using $\mathrm{DiIC}_{1}(5)$ (data not shown) according to Munoz et al. [23]. AxV/PI staining showed that SEON ${ }^{\mathrm{LA}-\mathrm{BSA}}$ and SEON ${ }^{\mathrm{DEX}}$ did not induce any cytotoxicity up to a tested concentration of $150 \mu \mathrm{g} / \mathrm{mL}$, whereas SEON ${ }^{\mathrm{LA}}$ induced cell death starting at $100 \mu \mathrm{g} / \mathrm{mL}$ (Figure 2). The rate of necrotic cells increased in a dose-dependent manner in $\mathrm{SEON}^{\mathrm{LA}}$-treated cells.

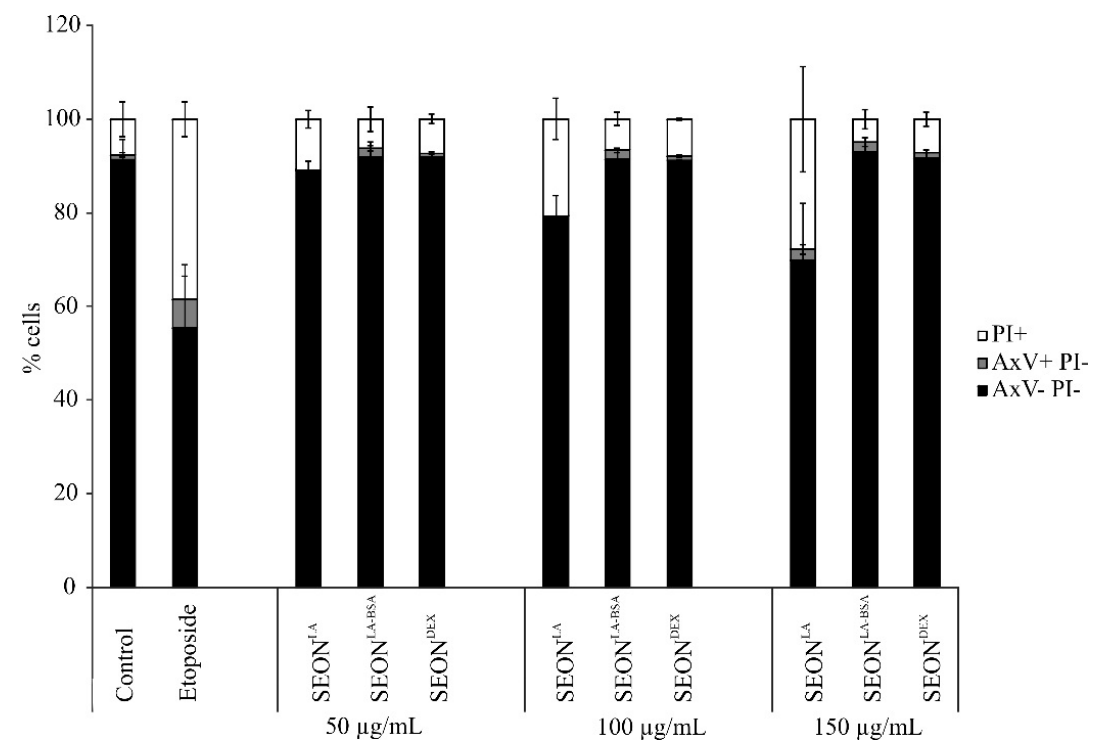

Figure 2. Cell death induction in HLG-5 cells. Cells were incubated with 50, 100, $150 \mu \mathrm{g} / \mathrm{mL}$ SPIONs for $48 \mathrm{~h}$. Etoposide-treated cells served as positive control; mock treated cells served as negative control. Cell viability was determined by AnnexinV-Fitc/propidium iodide (AxV/PI) staining. AxV-/PI- cells are considered viable, AxV+/PI- are apoptotic, and PI+ cells are necrotic. The mean values of $n=3$ with standard deviations are shown. 
As granulosa cells do not only protect the oocyte physically, but are furthermore very important for development, toxic effects of nanoparticles on these cells might be accompanied by reduced fertility or congenital defects. Although only few studies have focused on the effect of nanoparticles on reproductive cells to date, it has been demonstrated so far that magnetic nanoparticles do not affect functionality [24], whereas $\mathrm{ZnO}$ and $\mathrm{TiO}_{2}$ nanoparticles may have toxic effects on male gametes depending on their concentration and composition, and can affect sperm cell functionality [25]. Concerning female gametes, quantum dots have proved to be cytotoxic, consequently negatively influencing oocyte maturation and fertilization [26].

\subsection{Micronuclei Formation in Granulosa Cells after Incubation with SPION}

Micronuclei tests are used in toxicological screening to identify genotoxic substances according to OECD guidelines. Micronuclei are small cytoplasmic bodies formed in anaphase of mitosis or meiosis. They contain pieces of chromosomes, resulting in a lack of DNA information in one daughter cell. In microscopy, they can be recognized as small nuclei separate from the main nucleus and are enclosed in their own nuclear membrane. An augmented frequency of micronuclei serves as a biomarker for genotoxicity $[27,28]$.

Because of their small size some nanoparticles can easily penetrate through membranes directly to the nucleus. Here, they can interact with the DNA and thus being a potential genotoxic hazard [29]. Different concentrations (as indicated) of iron oxide nanoparticles SEON ${ }^{\mathrm{LA}-B S A}, \mathrm{SEON}^{\mathrm{DEX}}$ and SEON $^{\mathrm{LA}}$ were incubated with granulosa cells and analyzed for micronuclei formation after $48 \mathrm{~h}$ (Figures 3 and 4 ) and $72 \mathrm{~h}$ (data not shown) using flow cytometry and fluorescence microscopy. Flow cytometry analysis revealed no remarkable difference in the micronuclei number of SEON ${ }^{\mathrm{DEX}}$ and SEON ${ }^{\mathrm{LA}-\mathrm{BSA}}$ treated cells as compared to the untreated control (Figure 3). Whereas, for SEON ${ }^{\mathrm{LA}}$ induction of micronuclei was 0.12 -fold higher on average compared to control. This was confirmed via fluorescence microscopy (Figure 4). Vinblastine, which causes M phase specific cell cycle arrest by disrupting microtubule association (not shown), and the topoisomerase II $\alpha$ inhibitor etoposide were used as positive controls to induce micronuclei formation. So far, it is not clear whether cytotoxicity caused by high concentrations of SEON ${ }^{\mathrm{LA}}$ is a secondary effect of DNA damage and will have to be further investigated.

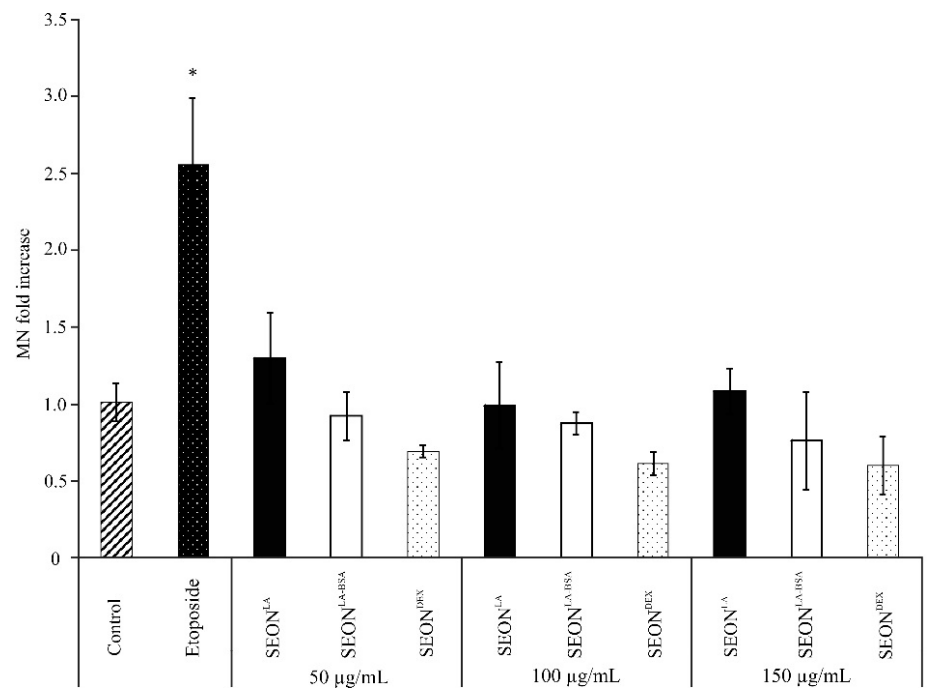

Figure 3. Flow cytometry of micronuclei in HLG-5 cells. Cells were treated with 50, 100 or $150 \mu \mathrm{g} / \mathrm{mL}$ iron oxide nanoparticles. Etoposide-treated cells served as positive control; mock treated cells served as negative control. After $48 \mathrm{~h}$ flow cytometry analysis using ethidium monoazide (EMA)/SYTOX green staining revealed no increase in micronuclei induction for SEON ${ }^{\text {LA-BSA }}$ and SEON $^{\mathrm{DEX}}$ compared to the control $\left({ }^{*} p<0.01, n=3\right)$. 


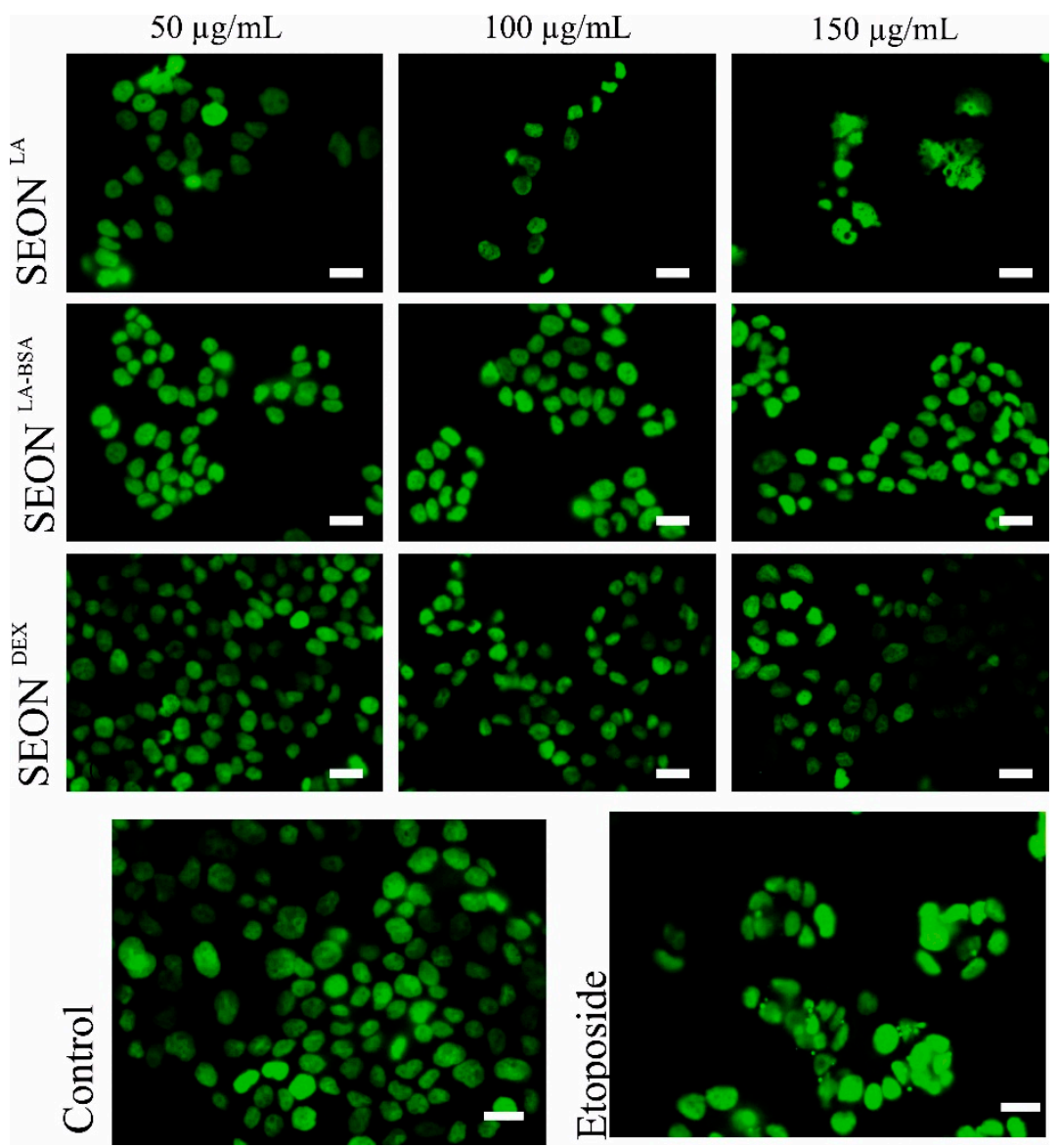

Figure 4. Fluorescence microscopy of micronuclei in HLG-5 cells. HLG-5 cells were treated for $48 \mathrm{~h}$ with 50, 100 and $150 \mu \mathrm{g} / \mathrm{mL} \mathrm{SEON}^{\mathrm{LA}}, \mathrm{SEON}^{\mathrm{LA}-B S A}$ and SEON ${ }^{\mathrm{DEX}}$, then DNA was stained with SYTOX green; SEON ${ }^{\text {LA-BSA }}$ and SEON ${ }^{\text {DEX }}$ showed no effect on cell morphology, whereas SEON ${ }^{\mathrm{LA}}$-treated cells appeared unhealthy compared to control. Many micronuclei can be recognized in etoposide-treated cells; (scale bars $=20 \mu \mathrm{m}$, representative pictures are displayed; $n=3$ ).

\subsection{DNA Damage in Granulosa Cells after Incubation with SPION}

Since micronuclei formation can be caused by DNA double strand breaks, this was evaluated by detection of phosphorylated H2A.X (Ser139) and ATM (Ser1981). The topoisomerase II $\alpha$ inhibitor etoposide is a very effective inductor of DNA double strand breaks, and brings cells into $\mathrm{G}_{2} / \mathrm{M}$ phase cell cycle arrest [30]. Following DNA double strand breaks, cell cycle checkpoint arrest and DNA repair requires phosphorylation of histone H2A.X at serine 139 by kinases such as ataxia telangiectasia mutated (ATM). Therefore, the phosphorylation of H2A.X ( $\gamma$-H2A.X) and ATM (pATM) is an important indicator of DNA damage [31].

Treatment of granulosa cells for $48 \mathrm{~h}$ with SEON ${ }^{\mathrm{LA}}$, SEON ${ }^{\mathrm{LA}-\mathrm{BSA}}$ and SEON ${ }^{\mathrm{DEX}}$ did not lead to phosphorylation of H2A.X or ATM compared to control cells, here summarized as "DNA damage" (Figure 5). This was also verified by western blot analysis (data not shown).

Different sources of DNA damage (exogen, endogen, mechanical) can cause a variety of DNA lesions and can thus induce various cellular reactions including cell cycle arrest, apoptosis and notably, DNA repair. DNA double strand breaks are supposed to be the furthermost disastrous forms of DNA destruction, conceding genomic stability. Therefore, it is very important to ensure nanoparticles safety upon DNA damage [32]. 


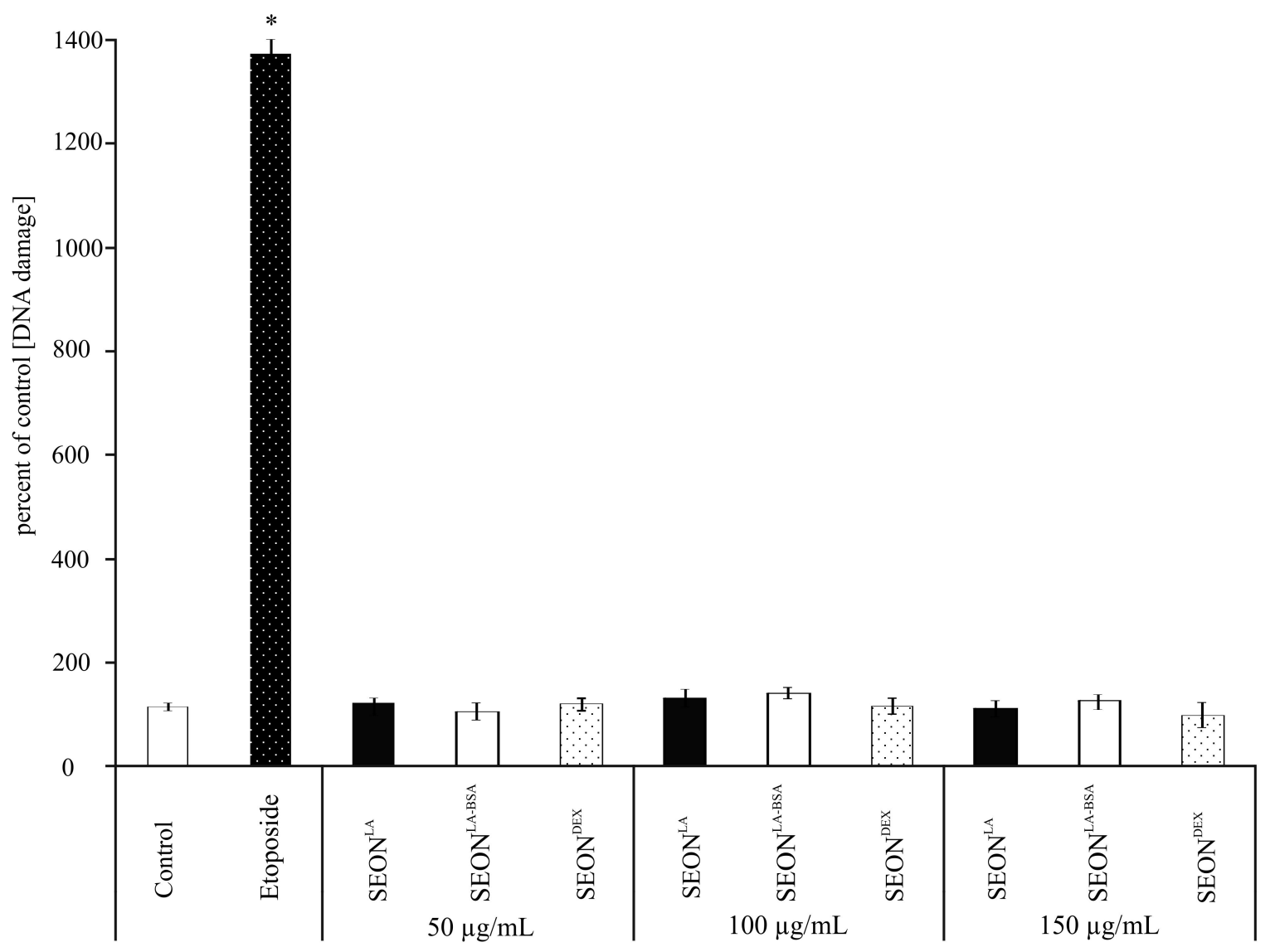

Figure 5. DNA damage (phosphorylation of H.2AX and ATM) in HLG-5 cells. Cells were incubated for $48 \mathrm{~h}$ with 50, 100 and $150 \mu \mathrm{g} / \mathrm{mL} \mathrm{SEON}^{\mathrm{LA}}, \mathrm{SEON}^{\mathrm{LA}-\mathrm{BSA}}$ and SEON ${ }^{\mathrm{DEX}}$. Mock treated cells served as negative controls; etoposide-treated cells served as positive controls $\left({ }^{*} p<0.01, n=3\right)$.

\section{Experimental Section}

\subsection{Nanoparticles}

All iron oxide nanoparticles used were comprehensively physico-chemically characterized previously by Zaloga et al., and Unterweger et al. [10,18]. Briefly, superparamagnetic iron oxide nanoparticles (SPIONs) were synthetized by co-precipitation in aqueous media (core size $7.64 \pm 1.6 \mathrm{~nm}$ ) and subsequent in-situ coating with lauric acid (LA), resulting in SEON ${ }^{\mathrm{LA}}$ to form a stable colloid. They were then additionally coated with bovine serum albumin (BSA) by dilution in excess protein solution and following removal of the unbound protein by ultrafiltration, resulting in SEON ${ }^{\text {LA-BSA }}[10,33]$. Upon formation of a BSA protein corona the $\zeta$ potential decreased drastically, indicating the high stability of aqueous dispersions of SEON ${ }^{\mathrm{LA}-\mathrm{BSA}}$. As expected, the surface charge of the SEON ${ }^{\text {LA-BSA }}$ particles was $\mathrm{pH}$ dependent, with the point of zero charge being just below $\mathrm{pH} 5$ which is very consistent with the isoelectric point of BSA [10].

For the synthesis of SEON ${ }^{\mathrm{DEX}}$, SPIONs were covered with dextran, the suspension was ultrafiltrated, and particle-bound dextran finally crosslinked [18]. In SEON ${ }^{\mathrm{DEX}}$ particles (core size $4.3 \pm 0.9 \mathrm{~nm}$ ) the dextran content during coprecipitation had an influence on the $\zeta$ potential. Formation of a stable colloid was first achieved with $2.0 \mathrm{~g}$ of dextran with a $\zeta$ potential of $-2.0 \pm 0.6 \mathrm{~nm}$. SEON ${ }^{\mathrm{DEX}}$ show an agglomeration of roundish magnetite particles embedded in a polymer matrix.

Synthesized SPIONs have a spherical morphology; Table 1 provides a summary of the basic physico-chemical nanoparticle characteristics. 
Table 1. Basic physico-chemical properties of SEON ${ }^{\mathrm{LA}}$, SEON ${ }^{\mathrm{LA}-B S A}$ and $\mathrm{SEON}^{\mathrm{DEX}}[10,18]$.

\begin{tabular}{cccc}
\hline Physico-Chemical Properties of Nanoparticles & SEON $^{\text {LA }}$ & SEON $^{\text {LA-BSA }}$ & SEON $^{\text {DEX }}$ \\
\hline Core diameter (TEM) (nm) in $\mathrm{H}_{2} \mathrm{O}$ & $7.64 \pm 1.6$ & $7.64 \pm 1.6$ & $4.3 \pm 0.9$ \\
Hydrodynamic diameter (DLS) (nm) in RPMI & $46.92 \pm 0.1$ & $61.7 \pm 1.1$ & $79 \pm 1.3$ \\
乙 potential (mV) in RPMI & $-15.5 \pm 0.8$ & $-12.9 \pm 0.55$ & $-2.0 \pm 0.6$ \\
Polydispersity index in RPMI & $0.331 \pm 0.019$ & $0.346 \pm 0.028$ & $0.304 \pm 0.031$ \\
\hline
\end{tabular}

\subsection{Cell Culture}

Briefly, human luteinized granulosa cells, HLG-5 were collected from infertile women undergoing In Vitro Fertilization (IVF) pre-embryo transfer treatment [34]. These cells duplicate every $48 \mathrm{~h}$ and were maintained in DMEM complemented with 10\% fetal calf serum (FCS) (both Biochrom, Berlin, Germany) under standard cell culture conditions in a humidified incubator (INCOmed, Memmert, Schwabach, Germany) at $37{ }^{\circ} \mathrm{C}$ and $5 \% \mathrm{CO}_{2}$. The cells were verified to be free of mycoplasma. For the experiments, the cells were grown to a confluence of $75 \%$ and passaged twice a week using $0.25 \%$ trypsin $/ 0.02 \%$ EDTA in PBS (PAN Biotech, Aidenbach, Germany).

\subsection{Live/Dead Staining Using Flow Cytometry}

HLG-5 cells were seeded at a concentration of $2 \times 10^{5}$ cells/ $\mathrm{mL}$ in 24 well plates. SEON nanoparticles (50, 100 and $150 \mu \mathrm{g} / \mathrm{mL}$ ) were added in $0.5 \mathrm{~mL}$; mock treated cells served as controls. After 24,48 , and $72 \mathrm{~h}$ the cells were trypsinized and resuspended in $1 \mathrm{~mL}$ DMEM. Fifty $\mu \mathrm{L}$ of cell solution was incubated with $250 \mu \mathrm{L}$ of freshly prepared staining solution, containing $1 \mu \mathrm{g} / \mathrm{mL}$ Annexin V-Fitc (AxV-Fitc), $1 \mu \mathrm{g} / \mathrm{mL}$ Hoechst 33342 (Hoe), $5.1 \mu \mathrm{g} / \mathrm{mL}$ DiIC $_{1}$ (5) (Dil) (all from Life Technologies, Darmstadt, Germany) and, $20 \mu \mathrm{g} / \mathrm{mL}$ propidium iodide ((PI), Sigma Aldrich, Taufkirchen, Germany) in Ringer's solution (Baxter Healthcare SA, Zurich, Switzerland) for 20 min at $4{ }^{\circ} \mathrm{C}$ [23].

\subsection{Micronuclei Test}

For immunofluorescence staining the culture medium was withdrawn. After a washing step with PBS (Sigma-Aldrich, St. Louis, MO, USA) and fixation with 3.7\% formaldehyde (AppliChem, Darmstadt, Germay) for $30 \mathrm{~min}$, cells were permeabilized for $10 \mathrm{~min}$ with $0.5 \%$ Triton X-100 (Sigma-Aldrich Chemie $\mathrm{GmbH}$, Steinheim, Germany). Afterwards cells were incubated $30 \mathrm{~min}$ with RNase $\left(10 \mathrm{mg} / \mathrm{mL}\right.$, Sigma-Aldrich). Staining of the nuclei was achieved with SYTOX green ${ }^{\circledR}$ for $20 \min (1 \mu \mathrm{M}$, Life Technologies, Eugene, OR, USA). Once one step was finished, slides were washed with PBS. Mounting medium was used to mount coverslips on glass slides (Dako North America, Inc., Carpinteria, CA, USA). The examination was made with a fluorescent microscope Axio Observer Z.1 with an ApoTome (Zeiss, Jena, Germany). Counting and recording of the micronuclei was performed as stated by Tolbert et al. [35], with some alterations. Micronuclei are defined as: sphere-shaped forms with a diameter of $1 / 3$ to $1 / 20$ of the central nucleus, micronuclei have to be in the same focus as the nucleus, they should be completely disconnected from the main nucleus and appear with a related shape of chromatin. For each sample set, 3000 cells were scored.

For flow cytometry analysis cells were trypsinized and centrifuged at $600 \mathrm{~g}$ for $5 \mathrm{~min}$; supernatant was discarded and cells were resuspended via moderate tapping. After adding $200 \mu \mathrm{L}$ PBS with $2 \%$ heat-inactivated fetal bovine serum (FBS), the cells were transferred into tubes containing $100 \mu \mathrm{L}$ nucleic acid staining solution $(125 \mathrm{mg} / \mathrm{mL}$ Ethidium monoazide in PBS with $2 \%$ FBS); (EMA, Molecular Probes by Life Technologies). The tubes were cooled in an ice box and photoactiviation was performed with a light source (60 W light bulb, Osram, Munich, Germany) for $20 \mathrm{~min}$ and with $30 \mathrm{~cm}$ distance to the tubes. Following photoactivation, $800 \mu \mathrm{L}$ of PBS with $2 \%$ FBS was supplemented and samples were transferred into $15 \mathrm{~mL}$ tubes with $8 \mathrm{~mL}$ PBS with $2 \%$ FBS. From this point samples were protected from light. After centrifugation at $600 \mathrm{~g}$ for $5 \mathrm{~min}$, the 
supernatant was discharged. The cells were resuspended by moderate tapping. $1 \mathrm{~mL}$ lysis solution 1 (deionized water, $0.584 \mathrm{mg} / \mathrm{mL} \mathrm{NaCl}, 1 \mathrm{mg} / \mathrm{mL}$ sodium citrate, $0.3 \mu \mathrm{L} / \mathrm{mL}$ IGEPAL (Sigma-Aldrich), $1 \mathrm{mg} / \mathrm{mL}$ RNase and $0.2 \mu \mathrm{M}$ SYTOX green ${ }^{\circledR}$ was added slowly, the tubes were immediately vortexed for $5 \mathrm{~s}$ and were set aside for $1 \mathrm{~h}$ at room temperature. Then lysis solution 2 (deionized water, $85.6 \mathrm{mg} / \mathrm{mL}$ sucrose, $15 \mathrm{mg} / \mathrm{mL}$ citric acid, and $0.2 \mu \mathrm{M}$ SYTOX green ${ }^{\circledR}$ ) was added quickly, followed by vortexing and kept at room temperature for another $30 \mathrm{~min}$. Tubes were kept at $4{ }^{\circ} \mathrm{C}$ until flow cytometric examination [36]. Tests for statistical significance were carried out using the Student's $t$-test in MS-Excel (Microsoft Corporation, Redmond, WA, USA).

\subsection{DNA Damage Detection}

HLG-5 cells were seeded at a concentration of $2 \times 10^{5}$ cells $/ \mathrm{mL}$ in 12 well plates (TPP Techno Plastic Products, Trasadingen, Switzerland). After $24 \mathrm{~h}$, different SEON nanoparticles (50, 100 and $150 \mu \mathrm{g} / \mathrm{mL}$ ) or $10 \mu \mathrm{M}$ positive control (etoposide) were added in $1 \mathrm{~mL}$; mock treated cells served as controls. After $48 \mathrm{~h}$ and $72 \mathrm{~h}$ (data not shown) DNA double strand breaks were detected using Muse $^{\mathrm{TM}}$ Multi-Color DNA Damage Kit (Merck Millipore, Darmstadt, Germany) [37] by staining $1 \times 10^{5}$ cells of each sample with anti-phospho-Histone H2A.X (Ser139) and anti-phospho-ATM (Ser1981) antibodies. Samples were acquired on the Muse ${ }^{\mathrm{TM}}$ Cell Analyzer (Merck Millipore). Tests for statistical significance were carried out using the Student's $t$-test in MS-Excel (Microsoft Corporation).

\subsection{Flow Cytometry}

Flow cytometry was performed via a Gallios cytofluorometer (Beckman Coulter, Pasadena, CA, USA). Electronic compensation was used to eliminate bleed over fluorescence. The data examination was done with Kaluza software, version 1.2 (Beckman Coulter). All flow cytometry experiments were conducted in triplicate, and the results were averaged.

\subsection{Microwave Plasma-Atomic Emission Spectrometer (MP-AES)}

For determination of absolute cellular iron content, $2 \times 10^{6}$ cells were incubated with $150 \mu \mathrm{g} / \mathrm{mL}$ nanoparticles. After $48 \mathrm{~h}$ the cells were washed, cell lysates were prepared from $1 \times 10^{6}$ cells and analyzed via Microwave Plasma-Atomic Emission Spectrometer, MP-AES 4200 (Agilent, Santa Clara, CA, USA). The entire iron level was ascertained at an emission wavelength of $371.993 \mathrm{~nm}$. For calibration external standards of iron at concentrations reaching from 0.01 to $2.5 \mu \mathrm{g} / \mathrm{mL}$ were utilized [38].

\section{Conclusions}

Little is known about the effects of nanoparticles on reproductive tissue and reproductively relevant cells. Gametes and the embryo are rather vulnerable and are therefore located in a more protected environment, but nanoparticles are most likely to cross these barriers, depending on composition, size and/or coating [39,40]. As nanoparticles are already being used in clinics or in clinical studies, they will be part of future medical applications, especially in diagnosis and therapy. Hence, it is of greatest significance to ensure the safety also of reproductive tissue. According to their field of application, e.g., contrast agents for diagnosis or as carriers of therapeutics in Magnetic Drug Targeting (MDT), these particles are coated with different materials. As we found no uptake of SEON ${ }^{\mathrm{DEX}}$ particularly in granulosa cells, they are considered to be suitable as contrast agents for magnetic resonance imaging (MRI), because they will most likely remain longer within the blood circulation. On the other hand, SEON ${ }^{\mathrm{LA}-\mathrm{BSA}}$ with very low toxicity and low uptake can be used for MDT in cancer or atherosclerosis therapy. In this study we demonstrated, that coating of iron oxide nanoparticles is essential to ensure biocompatibility. Future studies are urgently needed to guarantee the safe design of nanoparticles, especially for cells within reproductive tissues. 
Acknowledgments: This work was supported by the Bavarian State Ministry of the Environment and Consumer Protection (Germany), and by the Cluster of Excellence Engineering of Advanced Materials (EAM, Germany). We would also like to acknowledge Roman Pavlik for gaining access to the granulosa cells.

Author Contributions: Marina Pöttler, Christina Janko and Christoph Alexiou wrote the manuscript; Marina Pöttler and Andreas Staicu mainly performed the experiments; Jan Zaloga synthesized and characterized the SEON $^{\mathrm{LA}}$ and SEON ${ }^{\mathrm{LA}-B S A}$; Harald Unterweger synthesized and characterized the SEON ${ }^{\mathrm{DEX}}$; Bianca Weigel accomplished cell culture; Eveline Schreiber performed MP-AES and Simone Hofmann, Irmi Wiest and Udo Jeschke were responsible for HLG-5 upbringing and organization.

Conflicts of Interest: The authors declare no conflict of interest.

\section{References}

1. Jin, R.; Lin, B.; Li, D.; Ai, H. Superparamagnetic iron oxide nanoparticles for MR imaging and therapy: Design considerations and clinical applications. Curr. Opin. Pharmacol. 2014, 18, 18-27. [CrossRef] [PubMed]

2. Silva, A.C.; Oliveira, T.R.; Mamani, J.B.; Malheiros, S.M.; Malavolta, L.; Pavon, L.F.; Sibov, T.T.; Amaro, E., Jr.; Tannus, A.; Vidoto, E.L.; et al. Application of hyperthermia induced by superparamagnetic iron oxide nanoparticles in glioma treatment. Int. J. Nanomed. 2011, 6, 591-603.

3. Alexiou, C.; Tietze, R.; Schreiber, E.; Jurgons, R.; Richter, H.; Trahms, L.; Rahn, H.; Odenbach, S.; Lyer, S. Cancer therapy with drug loaded magnetic nanoparticles-Magnetic drug targeting. J. Magn. Magn. Mater. 2011, 323, 1404-1407. [CrossRef]

4. Tietze, R.; Lyer, S.; Durr, S.; Struffert, T.; Engelhorn, T.; Schwarz, M.; Eckert, E.; Goen, T.; Vasylyev, S.; Peukert, W.; et al. Efficient drug-delivery using magnetic nanoparticles-Biodistribution and therapeutic effects in tumour bearing rabbits. Nanomed. Nanotechnol. Biol. Med. 2013, 9, 961-971. [CrossRef] [PubMed]

5. Cicha, I.; Lyer, S.; Alexiou, C.; Garlichs, C.D. Nanomedicine in diagnostics and therapy of cardiovascular diseases: Beyond atherosclerotic plaque imaging. Nanotechnol. Rev. 2013, 2, 449-472. [CrossRef]

6. Lee, E.A.; Yim, H.; Heo, J.; Kim, H.; Jung, G.; Hwang, N.S. Application of magnetic nanoparticle for controlled tissue assembly and tissue engineering. Arch. Pharmacal. Res. 2014, 37, 120-128. [CrossRef] [PubMed]

7. Tietze, R.; Lyer, S.; Durr, S.; Alexiou, C. Nanoparticles for cancer therapy using magnetic forces. Nanomedicine 2012, 7, 447-457. [CrossRef] [PubMed]

8. Peng, M.; Li, H.; Luo, Z.; Kong, J.; Wan, Y.; Zheng, L.; Zhang, Q.; Niu, H.; Vermorken, A.; van de Ven, W.; et al. Dextran-coated superparamagnetic nanoparticles as potential cancer drug carriers in vivo. Nanoscale 2015, 7, 11155-11162. [CrossRef] [PubMed]

9. Wang, Y.X.; Hussain, S.M.; Krestin, G.P. Superparamagnetic iron oxide contrast agents: Physicochemical characteristics and applications in MR imaging. Eur. Radiol. 2001, 11, 2319-2331. [CrossRef] [PubMed]

10. Zaloga, J.; Janko, C.; Nowak, J.; Matuszak, J.; Knaup, S.; Eberbeck, D.; Tietze, R.; Unterweger, H.; Friedrich, R.P.; Duerr, S.; et al. Development of a lauric acid/albumin hybrid iron oxide nanoparticle system with improved biocompatibility. Int. J. Nanomed. 2014, 9, 4847-4866. [CrossRef] [PubMed]

11. Nel, A.; Xia, T.; Madler, L.; Li, N. Toxic potential of materials at the nanolevel. Science 2006, 311, $622-627$. [CrossRef] [PubMed]

12. Zhang, H.Y.; Ji, Z.X.; Xia, T.; Meng, H.; Low-Kam, C.; Liu, R.; Pokhrel, S.; Lin, S.J.; Wang, X.; Liao, Y.P.; et al. Use of Metal Oxide Nanoparticle Band Gap To Develop a Predictive Paradigm for Oxidative Stress and Acute Pulmonary Inflammation. Acs Nano 2012, 6, 4349-4368. [CrossRef] [PubMed]

13. Emerit, J.; Beaumont, C.; Trivin, F. Iron metabolism, free radicals, and oxidative injury. Biomed. Pharmacother. 2001, 55, 333-339. [CrossRef]

14. Voinov, M.A.; Sosa Pagan, J.O.; Morrison, E.; Smirnova, T.I.; Smirnov, A.I. Surface-mediated production of hydroxyl radicals as a mechanism of iron oxide nanoparticle biotoxicity. J. Am. Chem. Soc. 2011, 133, $35-41$. [CrossRef] [PubMed]

15. Kryston, T.B.; Georgiev, A.B.; Pissis, P.; Georgakilas, A.G. Role of oxidative stress and DNA damage in human carcinogenesis. Mutat. Res. 2011, 711, 193-201. [CrossRef] [PubMed]

16. Di Bona, K.R.; Xu, Y.; Ramirez, P.A.; DeLaine, J.; Parker, C.; Bao, Y.; Rasco, J.F. Surface charge and dosage dependent potential developmental toxicity and biodistribution of iron oxide nanoparticles in pregnant CD-1 mice. Reprod. Toxicol. 2014, 50, 36-42. [CrossRef] [PubMed] 
17. Bica, D.; Vekas, L.; Avdeev, M.V.; Marinica, O.; Socoliuc, V.; Balasoiu, M.; Garamus, V.M. Sterically stabilized water based magnetic fluids: Synthesis, structure and properties. J. Magn. Magn. Mater. 2007, 311, 17-21. [CrossRef]

18. Unterweger, H.; Tietze, R.; Janko, C.; Zaloga, J.; Lyer, S.; Durr, S.; Taccardi, N.; Goudouri, O.M.; Hoppe, A.; Eberbeck, D.; et al. Development and characterization of magnetic iron oxide nanoparticles with a cisplatin-bearing polymer coating for targeted drug delivery. Int. J. Nanomed. 2014, 9, 3659-3676. [CrossRef] [PubMed]

19. Friedrich, R.P.; Janko, C.; Poettler, M.; Tripal, P.; Zaloga, J.; Cicha, I.; Durr, S.; Nowak, J.; Odenbach, S.; Slabu, I.; et al. Flow cytometry for intracellular SPION quantification: Specificity and sensitivity in comparison with spectroscopic methods. Int. J. Nanomed. 2015, 10, 4185-4201. [CrossRef] [PubMed]

20. Gong, M.; Yang, H.; Zhang, S.; Yang, Y.; Zhang, D.; Qi, Y.; Zou, L. Superparamagnetic core/shell GoldMag nanoparticles: Size-, concentration- and time-dependent cellular nanotoxicity on human umbilical vein endothelial cells and the suitable conditions for magnetic resonance imaging. J. Nanobiotechnol. 2015, 13, 24. [CrossRef] [PubMed]

21. Gaihre, B.; Hee Lee, Y.; Khil, M.S.; Yi, H.K.; Kim, H.Y. In-vitro cytotoxicity and cell uptake study of gelatin-coated magnetic iron oxide nanoparticles. J. Microencapsul. 2011, 28, 240-247. [CrossRef] [PubMed]

22. Landgraf, L.; Christner, C.; Storck, W.; Schick, I.; Krumbein, I.; Dahring, H.; Haedicke, K.; Heinz-Herrmann, K.; Teichgraber, U.; Reichenbach, J.R.; et al. A plasma protein corona enhances the biocompatibility of $\mathrm{Au} @ \mathrm{Fe}_{3} \mathrm{O}_{4}$ Janus particles. Biomaterials 2015, 68, 77-88. [CrossRef] [PubMed]

23. Munoz, L.E.; Maueroder, C.; Chaurio, R.; Berens, C.; Herrmann, M.; Janko, C. Colourful death: Six-parameter classification of cell death by flow cytometry-Dead cells tell tales. Autoimmunity 2013, 46, 336-341. [CrossRef] [PubMed]

24. Makhluf, S.B.D.; Qasem, R.; Rubinstein, S.; Gedanken, A.; Breitbart, H. Loading magnetic nanoparticles into sperm cells does not affect their functionality. Langmuir ACS J. Surf. Colloids 2006, 22, 9480-9482. [CrossRef] [PubMed]

25. Gopalan, R.C.; Osman, I.F.; Amani, A.; de Matas, M.; Anderson, D. The effect of zinc oxide and titanium dioxide nanoparticles in the Comet assay with UVA photoactivation of human sperm and lymphocytes. Nanotoxicology 2009, 3, 33-39. [CrossRef]

26. Hsieh, M.S.; Shiao, N.H.; Chan, W.H. Cytotoxic effects of CdSe quantum dots on maturation of mouse oocytes, fertilization, and fetal development. Int. J. Mol. Sci. 2009, 10, 2122-2135. [CrossRef] [PubMed]

27. Goel, S.; Bhatia, A.; Dey, P. Spontaneously occurring micronuclei in infiltrating ductal carcinoma of breast: A potential biomarker for aggressive phenotype detection? Diagn. Cytopathol. 2013, 41, 296-302. [CrossRef] [PubMed]

28. Kumar, V.; Rao, N.N.; Nair, N.S. Micronuclei in oral squamous cell carcinoma. A marker of genotoxic damage. Indian J. Dent. Res. 2000, 11, 101-106. [PubMed]

29. Geiser, M.; Rothen-Rutishauser, B.; Kapp, N.; Schurch, S.; Kreyling, W.; Schulz, H.; Semmler, M.; Im Hof, V.; Heyder, J.; Gehr, P. Ultrafine particles cross cellular membranes by nonphagocytic mechanisms in lungs and in cultured cells. Environ. Health Perspect. 2005, 113, 1555-1560. [CrossRef] [PubMed]

30. Schonn, I.; Hennesen, J.; Dartsch, D.C. Cellular responses to etoposide: Cell death despite cell cycle arrest and repair of DNA damage. Apoptosis 2010, 15, 162-172. [CrossRef] [PubMed]

31. Tanaka, T.; Huang, X.; Halicka, H.D.; Zhao, H.; Traganos, F.; Albino, A.P.; Dai, W.; Darzynkiewicz, Z. Cytometry of ATM activation and histone H2AX phosphorylation to estimate extent of DNA damage induced by exogenous agents. Cytom. A: J. Int. Soc. Anal. Cytol. 2007, 71, 648-661. [CrossRef] [PubMed]

32. Wan, R.; Mo, Y.; Feng, L.; Chien, S.; Tollerud, D.J.; Zhang, Q. DNA damage caused by metal nanoparticles: Involvement of oxidative stress and activation of ATM. Chem. Res. Toxicol. 2012, 25, 1402-1411. [CrossRef] [PubMed]

33. Zaloga, J.; Stapf, M.; Nowak, J.; Pottler, M.; Friedrich, R.P.; Tietze, R.; Lyer, S.; Lee, G.; Odenbach, S.; Hilger, I.; et al. Tangential flow ultrafiltration allows purification and concentration of lauric acid-/albumin-coated particles for improved magnetic treatment. Int. J. Mol. Sci. 2015, 16, 19291-19307. [CrossRef] [PubMed]

34. Pavlik, R.; Wypior, G.; Hecht, S.; Papadopoulos, P.; Kupka, M.; Thaler, C.; Wiest, I.; Pestka, A.; Friese, K.; Jeschke, U. Induction of G protein-coupled estrogen receptor (GPER) and nuclear steroid hormone 
receptors by gonadotropins in human granulosa cells. Histochem. Cell Biol. 2011, 136, 289-299. [CrossRef] [PubMed]

35. Tolbert, P.E.; Shy, C.M.; Allen, J.W. Micronuclei and other nuclear anomalies in buccal smears-A field-test in snuff users. Am. J. Epidemiol. 1991, 134, 840-850. [PubMed]

36. Bryce, S.; Avlasevich, S.; Raja, S.; Torous, D.; Bemis, J.; Dertinger, S. Flow Cytometric in vitro Micronucleus Scoring Provides Simultaneous Mode of Action Information. Environ. Mol. Mutagen. 2009, 50, 582.

37. Santos, M.; Zhang, W.; Rollins, L.; Hsu, M. A Quantitative Approach for Interrogation of H2A.X and ATM DNA Damage Signaling Using Rapid Benchtop Flow Cytometry; Merck Millipore Application Note, Biocompare: South San Francisco, CA, USA, 2014.

38. Forte, G.; Alimonti, A.; Violante, N.; di Gregorio, M.; Senofonte, O.; Petrucci, F.; Sancesario, G.; Bocca, B. Calcium, copper, iron, magnesium, silicon and zinc content of hair in Parkinson's disease. J. Trace Elem. Med. Biol. 2005, 19, 195-201. [CrossRef] [PubMed]

39. Wick, P.; Malek, A.; Manser, P.; Meili, D.; Maeder-Althaus, X.; Diener, L.; Diener, P.A.; Zisch, A.; Krug, H.F.; von Mandach, U. Barrier capacity of human placenta for nanosized materials. Environ. Health Perspect. 2010, 118, 432-436. [CrossRef] [PubMed]

40. Myllynen, P.K.; Loughran, M.J.; Howard, C.V.; Sormunen, R.; Walsh, A.A.; Vahakangas, K.H. Kinetics of gold nanoparticles in the human placenta. Reprod. Toxicol. 2008, 26, 130-137. [CrossRef] [PubMed]

(C) 2015 by the authors; licensee MDPI, Basel, Switzerland. This article is an open access article distributed under the terms and conditions of the Creative Commons by Attribution (CC-BY) license (http://creativecommons.org/licenses/by/4.0/). 